\title{
Allelopathic activity of broom (Scoparia dulcis L.) on the germination of invasive plants
}

\author{
Erivania Virtuoso Rodrigues Ferreira ${ }^{1} \mathbb{\infty}$, Simone Paes Bastos Franco ${ }^{2}$, \\ Aldenir Feitosa Santos ${ }^{3}$, Renan Cantalice Souza ${ }^{1} \mathbb{C}$

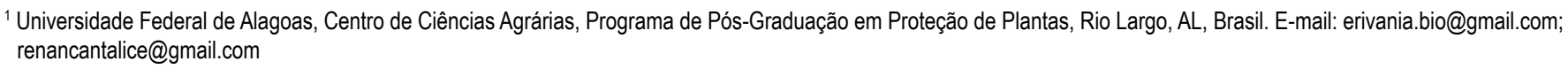 \\ ${ }^{2}$ Instituto Federal de Alagoas, Departamento de Química, Maceió, AL, Brasil. E-mail: simone_paes7@hotmail.com \\ 3 Universidade Estadual de Alagoas, Departamento de Química, Arapiraca, AL, Brasil. E-mail: aldenirfeitosa@gmail.com
}

ABSTRACT: Allelopathy is characterized by effects on plant germination or development caused by chemicals released by other plants. This work aimed to verify the allelopathic activity of Scoparia dulcis leaves and roots in weeds and lettuce, as well as to determine the phenolic compounds present in the studied plant. The experiment was arranged in a $2 \times 5$ factorial design, with six replications of 15 seeds each. The seeds were placed to germinate in agar layers, and after ten days were evaluated the germination percentage, shoot length and root primary length. Phytochemical analysis using high performance liquid chromatography was also carried out, in which the samples were injected three times in the chromatographic system to obtain the average concentrations and retention times, allowing to identify and quantify the studied metabolites. The results showed that this species has allelopathic potential, as it interfered in the development of all receiving plants studied, and the inhibitory action exerted by the leaves was more significant/ou intense on the analyzed variables. On the other hand, the roots presented a larger total amount of phenolic compounds, being caffeic acid found in greater amount both in the roots and leaves.

Key words: allelochemicals; inhibition; phenolic compounds

\section{Atividade alelopática da vassourinha (Scoparia dulcis L.) na germinação de plantas invasoras}

RESUMO: A alelopatia se caracteriza por efeitos na germinação ou no desenvolvimento das plantas, causados por substâncias químicas que são produzidas por outras. Este trabalho objetivou-se verificar a atividade alelopática das folhas e raízes de Scoparia dulcis em plantas daninhas e em alface, bem como determinar os compostos fenólicos presentes na planta estudada. $O$ experimento foi organizado em esquema fatorial $2 \times 5$, com seis repetições de 15 sementes cada. As sementes foram colocadas para germinar em camadas de ágar, e ao final de dez dias foram avaliados o percentual de germinação, 0 comprimento da parte aérea e o comprimento primário da raiz, além do estudo fitoquímico por cromatografia líquida de alta eficiência em que as amostras foram injetadas três vezes no sistema cromatográfico, para se obter a média das concentrações e dos tempos de retenção, possibilitando a identidade e quantidade dos metabólitos estudados. Os resultados demonstraram que esta espécie possui potencial alelopático, pois interferiu no desenvolvimento de todas as plantas receptoras estudadas, sendo que a ação inibitória exercida pelas folhas foi mais drástica sobre as variáveis analisadas. Já as raízes, apresentaram maior quantidade total de compostos fenólicos, sendo o ácido cafeico, encontrado em maior quantidade tanto nas raízes como nas folhas.

Palavras-chave: aleloquímicos; inibição; compostos fenólicos 


\section{Introduction}

Over time, when annual crop lands are left fallow for a specific period of time in the year, weed plants establish and predominate in the area, and it is well known that they release chemical substances from the secondary metabolism with positive or negative effects on the germination processes of other species (Souto et al., 2015). This phenomenon was termed allelopathy, and the substances responsible for these properties, allelochemicals. When these chemicals are released in sufficient amounts, they cause allelopathic effects which can be observed in the germination, growth and/or development of plants already established (Gonçalves, 2016).

Secondary metabolites were long been considered residual products from metabolism without a particular function in plants. But, like the primary ones, they are closely associated with vital plant processes (attraction of pollinating agents or seeds dispersers, protection against radiation, nitrogen storage and regulation of the plants' water balance) and are classified, according to their chemical structure, as nitrogenous, terpenoids and phenolics. During the evolution process, they represented some advantage against the action of microorganisms, viruses, insects and other pathogens or predators, either by inhibiting their action or stimulating the plants' growth or development (Souto et al., 2015).

Studies on the allelopathic influences between species are all-important because they enable to know the effects and inter- and intraspecific interactions of plants, which can be noticed, for instance, in germination and in the emergence speed index (Oliveira et al., 2014). In agriculture, knowledge on allelopathy in many cases helps identify the causes of failure in crops, as this phenomenon occurs very often in plant communities, and for this reason it is vitally important in crops management. There are some cases in which the plant of interest has an allelopathic effect on some weed species. Such allelopathic effect can be used as a control strategy, diminishing the use of herbicides, reducing contamination of food crops, environmental pollution, and production costs (Khawar et al., 2015).

Scoparia dulcis L., commonly known as sweet broomweed, licorice weed, or vassourinha in Brazil, has a pantropical distribution, is found in natural open areas with high infestation in pastures and crop lands. It is an annual herbaceous plant, reproduced by seeds, a subwoody stem at base, erect up to $80 \mathrm{~cm}$ tall, largely branched with upward branches, in a structure that allows its use as a "broom". In addition, it has a very short reproductive cycle and the ability to adapt to different agricultural environments, forming clusters and inhibiting the establishment of other plants (Souza \& Hassemer, 2015). And, according to Lanna et al. (2012), in a preliminary evaluation of secondary metabolites in $S$. dulcis, phytochemical tests detected the presence of saponins, polysaccharides, organic acids (carotenoids and steroids), triterpenoids, catechic tannins, and reducing sugars, which makes this species potentially capable of interfering with the development of other plants.
Studies on allelopathy utilize diverse parameters to investigate the harmful effects of the substances tested. Among these parameters, we can cite: germination index, germination speed index, root length, fresh biomass, dry biomass, average germination time, rate of normal seedling development, shoot length, hypocotyl elongation, number of dead and non-germinated seeds, emergence speed index, emergence rate, in addition to micro morphological aspects of seedlings (Nunes et al., 2014; Silveira et al., 2014). In this regard, in this study we used lettuce seeds, considered sensitive to allelopathy tests (Andrade-Vieira et al., 2014), and seeds of sourgrass, tasselflower, purslane, weed plants commonly found in crop and pasture lands in the Zona da Mata (Forest Zone) region and in the coastal plains in the state of Alagoas.

Given the above, the aim of this study was to investigate the allelopathic potential of leaves and roots of Scoparia dulcis in the germination and initial development of lettuce (Lactuca sativa L.), tasselflower (Emilia fosbergii Nicolson), purslane (Portulaca oleracea L.) and sourgrass (Digitaria insularis (L.) Fedde) as an alternative to be used in weed control, thus contributing to expand the eco-physiological knowledge on this species.

\section{Materials and Methods}

The experiment was developed at the Laboratory of Plant Biotechnology, Center of Agricultural Sciences (CECA), Federal University of Alagoas (UFAL), located in Rio Largo/AL (latitude 9o $27^{\prime} \mathrm{S}$, longitude 350 27' $\mathrm{W}$ and altitude $127 \mathrm{~m}$ ). The donor plant was collected at the reproductive stage (Herbarium MAC, 64850) from natural infestation areas at the Center of Agricultural Sciences and later divided into two parts: aboveground part (shoots) and roots. After collection, the material was washed in running water to remove impurities and taken to an air-circulation oven at $60 \stackrel{\circ}{\circ}$ to constant weight. Then, it was stored in plastic bags and kept under refrigeration until use.

The seeds of weed species (Digitaria insularis (L.) Fedde, Herbarium MAC 64848; Emilia forbergii Nicolson, Herbarium MAC 64847; and, P. oleracea, ESTÉRIL), considered as recipient plants in this study, were hand harvested between April and July, also in the infestations areas in the Center of Agricultural Sciences and subjected to cleaning and purging process and stored under refrigeration. The seeds of the bioindicator $L$. sativa (lettuce - Iceberg cultivar) were obtained commercially.

The seeds asepsis consisted in washing them with detergent during two minutes and then, after rinsing with distilled water, they were placed into an agitator, at rotation five, in $100 \mathrm{~mL}$ of $1 \%$ sodium hypochlorite during 15 minutes. Afterwards, the seeds were washed with sterile water and introduced into the culture medium for in vitro germination.

For the bioassays, we used the methodology described by Fujii et al. (2004), pouring $5 \mathrm{~mL}$ of agar solution into six-well agar plates. This solution was prepared with seven grams of agar in one liter of water and sterilized in autoclave at $121 \stackrel{\circ}{\circ}$ 
during 30 min. Dry matter of leaves and roots of the studied plant were placed onto the agar layer at concentrations of $0.01,0.02,0.04$ and 0.08 grams $(\mathrm{g})$, and then covered with additional $5 \mathrm{~mL}$ of agar on the top of the first layer. In the control treatment, there was no addition of plant matter to the agar solution $(0.00 \mathrm{~g})$. After $24 \mathrm{~h}, 15$ seeds of the recipient plants were randomly sown in each plate well.

The plates were hermetically sealed with Parafilm ${ }^{\circledR}$, labeled and kept under constant temperature $(25 \stackrel{\circ}{\circ})$ and controlled light (12-hour photoperiod), in a germination room during ten days. After this period, the seedling germination and growth rates were determined.

The radicle protrusion and geotropic curvature were utilized as criteria for assessment of germination, according to the Regras para Análise de Sementes (Rules for Seed Testing) (Brasil, 2009), considering as normal seedlings all those that exhibited the embryo essential structures developed and, at least, with $2 \mathrm{~mm}$ long radicle. The seedling length was assessed along with germination, when six normal seedlings were harvested and the shoots length (SL) and the primary root length (PRL) were assessed using a millimeter rule (Fujii et al. 2004).

After the preemergence bioassays, the nutrition medium (agar layers), still with the plant material between the layers, was left for a maceration process with methanol, and every 48 hours the solvent was removed from the material by rotary evaporation, and this operation was repeated three times. The extract underwent phytochemical prospection analysis using High-Performance Liquid Chromatography.

To check for existing phenolic compounds in the leaves and roots of the tested plant, some standards were selected, obtained from Sigma-Aldrich and AcrosOrganics, to compare them with the compounds present. The secondary compounds utilized in this study were chosen according to their participation in allelopathic phenomena described in literature (Santos \& Rezende, 2008; Oliveira et al., 2014; Fiorenza et al., 2016; Franco et al., 2016; Peloi et al., 2016; Pereira et al., 2018), namely: gallic acid, catechol, vanillic acid, salicylic acid, vanillin, syringaldehyde, coumaric acid, chlorogenic acid, coumarin, rutin, quercetin, kaempferol, and caffeic acid. All solvents utilized in chromatography were of analytical grade; methanol (Panreac), formic acid (dynamic) and ultrapure water obtained from a Milli-Q system.

The equipment used was a HPLC (Shimadzu) equipped with four high-pressure pumps model LC-20AT, degasser model DGU-20A 5R, interface model CBM-20A, automatic injector model SIL-20A HT, and detector model SPD-20A. The chromatographic column used in both analyses was Agilent Zorbax Eclipse XDB-C18 (4.6 x $250 \mathrm{~mm}, 5 \mu \mathrm{m})$.

For the standards, stock-solutions were prepared at a concentration of $40 \mathrm{mg} \mathrm{L}-1$ in $30 \%$ water/70\% alcohol. Quantification was achieved using external standards, where an intermediate solution containing a mixture of all standards was diluted, which was obtained by diluting stock solutions previously prepared, to build the analytical curves. In this intermediate solution, all standards were at a concentration of $10 \mathrm{mg} \mathrm{L}^{-1}$ and, for the mobile phase for the elution of the compounds analyzed, $1 \%$ formic acid solution in Milli-Q water and methanol was used.

The samples and standards were filtered through a Millipore polyethylene membrane with $0.45 \mu \mathrm{m}$ pore size and injected directly into the chromatographic system. Each injection was performed three times in the HPLC system to obtain the average concentrations and retention times. Gradient elutions were carried out using a total runtime of 80 minutes, wavelength of $290 \mathrm{~nm}$, temperature of $33^{\circ} \mathrm{C}$, with flow rate of $0.6 \mathrm{~mL} \mathrm{~min}^{-1}$ and injection volume of $20 \mu \mathrm{L}$. Thus, the identity of the analytes was confirmed by the retention time, and the profile of the sample peaks was compared to the standards.

The mean values resulting from the phytochemical analysis refer to the original data, but the data obtained from the assessments of the other parameters were subjected to analysis of variance using SISVAR software. The values of the control treatment for the germination rate were considered $100 \%$ (relative percentage), the results of each treatment being calculated in relation to the control. For the SL and PRL variables, the means refer to original data, in $\mathrm{cm}$.

The effect being significant to determine $\mathrm{LC}_{50}$ (lethal concentration equivalent to $50 \%$ of effect in relation to the control), data were adjusted to the exponential decay nonlinear regression model with two parameters using the SIGMAPLOT program (Streibig, 1988). LC 50 is the extract concentration that provides $50 \%$ of control or growth reduction of the recipient species (adapted from Christoffoleti \& López-Ovejero, 2008).

\section{Results and Discussions}

In the present study, all regressions for the parameters assessed fit the exponential decay model (Table 1), especially the leaves, which exhibited a behavior with high values of the coefficient of determination $\left(R^{2}\right)$.

The substances released by the leaves of $S$. dulcis exhibited inhibitory effects on the germination of seeds of all recipient species. In a similar study, Souza Filho (2014) reported that the crude extract of leaves from Sclerolobium paniculatum indicated a strong allelopathic activity, as it inhibited about $100 \%$ of germination of three different weed species. Nunes et al. (2014) used water extract from leaves of pink trumpet tree (Handroanthus heptaphyllus) at different concentrations to test its efficacy in suppressing germination of some seeds, among them sourgrass (Digitaria insularis), and observed that all concentrations interfered with germination, also corroborating the present study.

With respect to roots, $P$. oleracea was less sensitive to the chemical compounds present in the roots of $S$. dulcis, and the most significant effects were found in the $E$. fosbergii and $D$. insularis species (Figure 1A and $1 D$ ). This result is interesting from the agronomic and ecological point of view because inhibited germination of weed plants may keep the crop free from competitors for a longer period of time, thus reducing the number of applications of synthetic herbicides that contaminate subsoils. 
Table 1. Estimates of parameters $a$ and $b$ of the coefficient of determination $\left(R^{2}\right)$ of the exponential decay model for germination (G), shoots length (SL) and primary root length (PRL) of seeds and seedlings of recipient species (L. sativa, $D$. insularis, E. fosbergii and $P$. oleracea), using leaves and roots of Scoparia dulcis.

\begin{tabular}{|c|c|c|c|c|}
\hline \multicolumn{5}{|c|}{ Leaves } \\
\hline \multirow{2}{*}{$\begin{array}{l}\text { Recipient } \\
\text { species }\end{array}$} & \multicolumn{3}{|c|}{ Parameters } & \multirow{2}{*}{$\mathbf{F}$} \\
\hline & A & B & $\mathbf{R}^{2}$ & \\
\hline \multicolumn{5}{|c|}{ Germination (G) } \\
\hline L. sativa & 99.43 & 105.24 & 0.99 & 434.1453 \\
\hline D. insularis & 99.99 & 1503.56 & 0.99 & 330.5887 \\
\hline E. fosbergii & 102.15 & 55.60 & 0.99 & 133.4932 \\
\hline P. oleracea & 98.36 & 63.82 & 0.99 & 207.6439 \\
\hline \multicolumn{5}{|c|}{ Roots } \\
\hline L. sativa & 75.48 & 22.62 & 0.62 & 1.9371 \\
\hline D. insularis & 106.03 & 51.69 & 0.84 & 7.5623 \\
\hline E. fosbergii & 95.43 & 77.22 & 0.86 & 8.8261 \\
\hline P. oleracea & 123.04 & 5.46 & 0.51 & 1.0641 \\
\hline \multicolumn{5}{|c|}{ Shoots length (SL) } \\
\hline L. sativa & 1.00 & 35.26 & 0.97 & 47.9832 \\
\hline D. insularis & 0.38 & 1294.16 & 0.97 & 71.8491 \\
\hline E. fosbergii & 0.72 & 42.54 & 0.95 & 30.7988 \\
\hline P. oleracea & 0.26 & 19.99 & 0.76 & 4.2577 \\
\hline \multicolumn{5}{|c|}{ Roots } \\
\hline L. sativa & 0.60 & 16.49 & 0.82 & 6.1511 \\
\hline D. insularis & 0.47 & 24.34 & 0.60 & 1.7182 \\
\hline E. fosbergii & 0.82 & 20.50 & 0.79 & 5.2949 \\
\hline P. oleracea & 0.27 & 1.19 & 0.32 & 0.3610 \\
\hline \multicolumn{5}{|c|}{ Primary root length (PRL) } \\
\hline L. sativa & 2.64 & 51.28 & 0.99 & 5157.2312 \\
\hline D. insularis & 4.13 & 1536.37 & 0.99 & 1788.6738 \\
\hline E. fosbergii & 1.60 & 106.83 & 0.98 & 68.2260 \\
\hline P. oleracea & 1.56 & 80.06 & 0.99 & 268.1014 \\
\hline \multicolumn{5}{|c|}{ Roots } \\
\hline L. sativa & 1.94 & 17.88 & 0.80 & 5.3237 \\
\hline D. insularis & 4.12 & 70.01 & 0.86 & 8.5807 \\
\hline E. fosbergii & 1.84 & 25.26 & 0.89 & 12.5403 \\
\hline P. oleracea & 2.48 & 15.31 & 0.69 & 2.7497 \\
\hline
\end{tabular}

It was also observed that the substances possibly released at the greatest concentration $(0.08 \mathrm{~g})$ were those that provided the highest inhibition effect, irrespective of the recipient plant (Figure 1A, 1B, 1C, 1D, 1E and 1F). These results show that the allelopathic effects of extracts depend on the concentration in which the substance is present. On the other hand, it can also be seen that the parts used (roots and leaves) are relevant, considering that differences were observed when extracts from different plant parts were used with the same concentrations.

Concerning the initial growth stage of the recipient plants, the leaves from $S$. dulcis caused a more significant inhibition in the seedlings' hypocotyls than in the roots, compared to the control treatment (Figure $1 B$ and $1 \mathrm{E}$ ). It was also observed a significant influence of all tested concentrations of extracts from leaves of $S$. dulcis, while in the presence of root only significant differences were found for the greatest concentration. Studies conducted by Zhi-Cong et al. (2016) found that the allelopathic effect of water extract from Wedelia trilobata (Asteraceae) on seeds of L. sativa and Eupatorium
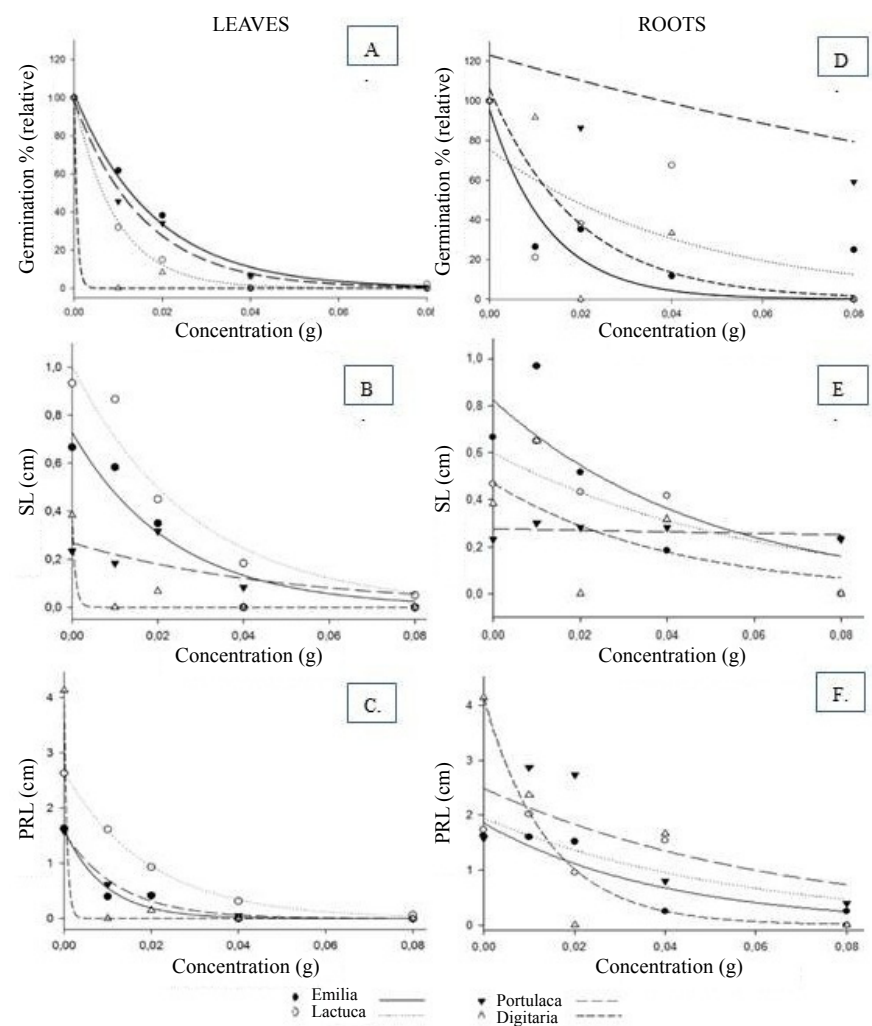

Figure 1. Percentage of germination, shoots length (SL) and primary root length (PRL) of seeds and seedlings of recipient species (L. sativa, $D$. insularis, $E$. fosbergii and $P$. oleracea), as a result of increasing concentrations of leaves $(A, B$ and $C)$ and roots (D, E and F) from Scoparia dulcis.

catariun caused a reduction of the seedlings length as the concentration increased. Inhibition of the hypocotyl growth of a species in in vitro assay enriched with plant extracts is commonly seen as an evidence of allelopathic interaction.

According to Figure $1 \mathrm{E}$, the increasing concentrations of S. dulcis roots influenced negatively the shoots length of the recipient species, especially $D$. insularis, and the $P$. oleracea species did not respond to such inhibition. The latter was the species that was less sensitive to the effects of the chemical compounds of this study, especially when tested with roots of S. dulcis, differing significantly from the other recipient plants, but differing little from the control treatment. In this regard, allelopathy is an alternative to integrated weed management due to the plants' ability to produce allelochemicals that inhibit or stimulate other plants' growth.

The radicle length of the seedlings of the recipient plants was also adversely affected by the greatest concentrations of leaves and roots of the donor plants assessed. The shortest root's lengths were found in the presence of leaves, indicating a sharp decrease of $50 \%$ already from the lowest concentration assessed (Figure 1C). Data available in literature show that allelopathic effects depend, among other factors, on the concentration of allelochemicals. The higher the allelochemical concentration, the greater its deleterious action on the metabolic processes of the target plant (KatoNoguchi et al., 2014). 
Still, according to the results, the concentrations of 0.04 and $0.08 \mathrm{~g}$, of both leaves and roots, exhibited more intense inhibitions. The seedlings exhibited a radicle length shorter than $1.0 \mathrm{~cm}$ for the greatest concentration (Figure $1 \mathrm{C}$ and $1 \mathrm{~F}$ ). These effects on the root primary growth may slow down or inhibit the development of weed plants, because they coincide with the initial stages of the plant's development.

The toxic action of the allelochemicals present in the leaves of $S$. dulcis was also observed in the seedlings' appearance. The greatest concentrations caused darkening and atrophy of the roots from $P$. oleracea. These symptoms resulted, according to Yamagushi et al. (2011), from the action of toxic substances present in the extracts on the root meristem and may induce production of reactive oxygen species (ROS) and cause tissue death. Germination may suffer the influence of allelochemicals action, but such effects are more effective on the root's growth, as similarly observed by other authors (Konstantinović et al., 2014). In general, the roots are more sensitive to the substances present in the extracts when compared to the other seedling structures because they are in a more direct and prolonged contact with the allelochemicals than other structures.

Based on the dose-response curves, which determine the inhibitory concentration equivalent to $50 \%$ of effect in relation to the control $\left(\mathrm{LC}_{50}\right)$, it was found that for germination, the $L$. sativa species exhibited lower $\mathrm{LC}_{50}$ when tested with leaves from $S$. dulcis while the $D$. insularis species suffers the allelopathic effects at a lower concentration of roots of the species studied (Table 2).

Concerning shoots length and primary root length, $D$. insularis was also the most sensitive species to the allelochemicals present in both leaves and roots of $S$. dulcis. According to Pirzad et al. (2010), the highest reduction of seedlings length was with concentrations of 15 and $20 \%$,

Table 2. Lethal concentration, $50 \%$, based on the parameters $a$ and $b$ of the exponential decay model for germination, shoots length (SL) and primary root length (PRL) of seeds and seedlings of recipient species (L. sativa, D. insularis, $E$. fosbergii and $P$. oleracea), subjected to leaves and roots of $S$. dulcis.

\begin{tabular}{ccc}
\hline Recipient species & Leaves & Roots \\
\hline & $\mathrm{G}$ & \\
\hline L. sativa & 0.006 & 0.017 \\
D. insularis & 4.611 & 0.014 \\
E. fosbergii & 0.012 & 0.067 \\
P. oleracea & 0.010 & 0.166 \\
\hline & $\mathrm{SL}$ & \\
\hline L. sativa & 0.110 & 0.268 \\
\hline . insularis & 0.003 & 0.191 \\
E. fosbergii & 0.099 & 0.200 \\
P. oleracea & 0.262 & 4.350 \\
\hline & $\mathrm{PRL}$ & \\
\hline L. sativa & 0.057 & 0.181 \\
\hline . insularis & 0.001 & 0.035 \\
E. fosbergii & 0.032 & 0.130 \\
P. oleracea & 0.043 & 0.196 \\
\hline
\end{tabular}

showing that, depending on the donor species, there is a difference in the concentration that is necessary to exhibit the allelopathic effect of $50 \%$ of in the recipient species.

The identification of compounds present in agar using High-Performance Liquid Chromatography (HPLC) of leaves and roots of Scoparia dulcis (Figure 2) showed the presence of seven polyphenols, in agreement with studies conducted by Lanna et al.(2012), in a preliminary evaluation of the secondary metabolites of this species, and phenolic acids, coumarins and kaempferol were indicated in both parts tested of the studied plant. According to Peloi et al. (2016), these metabolites were already detected in phytochemical analyses with other plants: in stems, leaves and roots of Vitex gardneriana; in shoots of Priva lappulacea (L.) and fruits of Duranta repens L., being largely known and identified in other studies (Franco et al., 2016; Pereira et al., 2018; Ferreira, 2019) with plants considered allelopathic because they can inhibit germination and growth of plants (Oliveira et al., 2014), phenomena found in the recipient plants of this study, suggesting that the
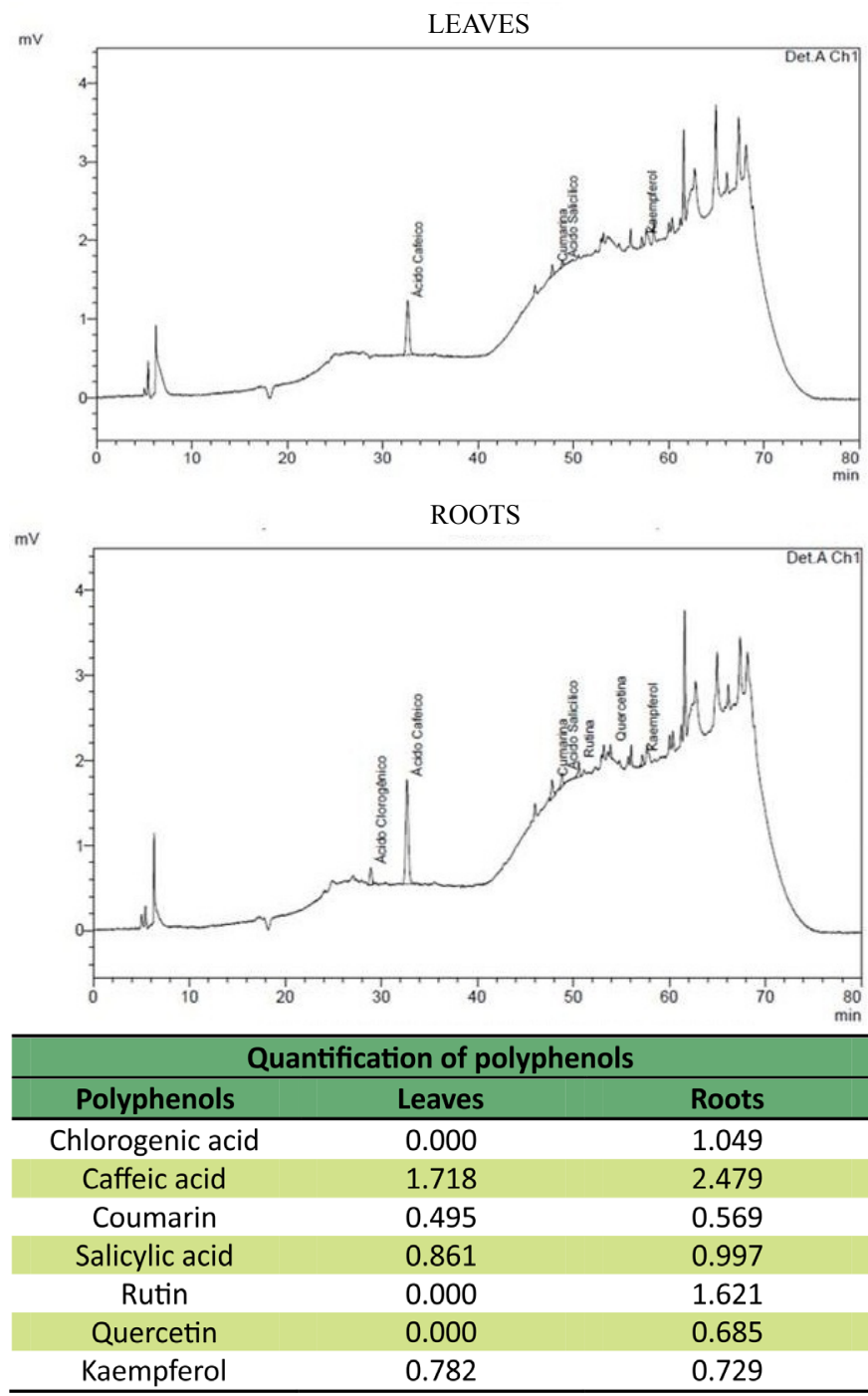

Figure 2. Chromatogram and quantification of polyphenols present in the nutrient medium used in treatments with leaves and roots of Scoparia dulcis. 
extracts utilized in the bioassays for preliminary diagnosis of allelopathy are mixtures of these substances, which can exert additive or synergistic effects, which makes important the analysis of action of each substance alone.

According to the results shown in Figure 2, chlorogenic acid, rutin and quercetin were detected in the studied plant roots. These secondary metabolites may alter the plants' nutrient balance (Santos \& Rezende, 2008), affecting their development. Fiorenza et al. (2016) tested an extract from Eragrostis plana Nees (Poaceae) and found a reduction in seeds germination, in the germination speed index and in initial development of seedlings, in all species investigated, and the presence of chlorogenic acid and rutin was identified, possibly being the allelopathic effect caused by these secondary metabolites, therefore corroborating this study. Thus, the germination and initial growth of seedlings suffered the phytotoxic effect caused by the allelopathic substances leached from the roots of the donor plants.

Flavonoids (rutin and quercetin) and phenolic acids (chlorogenic and caffeic acids) were found by Golisy et al. (2007) in the species Fagopyrum esculentum (Polygonaceae), causing and allelopathic effect on L. sativa, rutin being the main responsible for the inhibition of the seedlings' growth. Therefore, these results are similar to the ones found in this study, as they interfered, in varying intensities, with the parameters here assessed.

The distinct behavior observed in the evaluation of the parameters studied, in the recipient species, can be explained by the fact that some substances, as phenolic acids, flavonoids and chlorogenic acid have stimulated the initial development of the seedlings, causing growth rates much higher than the control; the second explanation could be that even when extracts contain amino acids, nutrients and compounds that stimulate growth, they also have allelochemicals that enter through the roots and after some time express the biological effects (reduced development) due to the addition of these substances.

Based on these studies, it can be inferred that the phenolic acids and flavonoids found in the extracts from the studied plant contributed to reduce germination and the seedlings length of the recipient species investigated. These results corroborate the inhibition data of the recipient species, when subjected to the compounds identified in this study, demonstrating that the allelopathic effect can be due to the presence of these secondary metabolites.

\section{Conclusion}

The leaves and roots of the species Scoparia dulcis have an allelopathic potential, causing interference with seeds germination and the initial development of lettuce, tasselflower, purslane and sourgrass plants.

The use of allelopathy, due to its excellent potential of interaction can be considered a viable alternative for weed management, allowing the use of allelopathic compounds in the production of bioactive substances.

\section{Acknowledgements}

The authors gratefully acknowledge financial support from the Coordination for the Improvement of Higher Education Personnel (CAPES) and the National Council for Scientific and Technological Development (CNPq).

\section{Literature Cited}

Andrade-Vieira, L.F.; Botelho, C.M.; Palmieri, M.J.; Laviola, B.G; PraçaFontes, M.M. Effects of Jatropha curcas oil in Lactuca sativa root tip bioassays. Anais da Academia Brasileira de Ciências, v.86, n.1, p.373-382, 2014. https://doi.org/10.1590/00013765201420130041.

Brasil. Ministério da Agricultura e Reforma Agrária. Secretaria de Defesa Agropecuária. Regras para análise de sementes. Brasília: Mapa; ACS, 2009. 399 p. http://www.agricultura.gov. $\mathrm{br} /$ assuntos/insumos-agropecuarios/arquivos-publicacoesinsumos/2946_regras_analise_sementes.pdf. 22 Jun. 2019.

Christoffoleti, P.J.; López-Ovejero, R.F. Resistência das plantas daninhas a herbicidas: definições, bases e situação no Brasil e no mundo. In: Christoffoleti, P.J. (Coord.). Aspectos de resistência de plantas daninhas a herbicidas. 3.ed. Piracicaba: Associação Brasileira de Ação à Resistência de Plantas Daninhas, 2008. p.934.

Ferreira, E.V.R. Atividade alelopática e compostos fenólicos de plantas daninhas pelo método sanduíche. Rio Largo: Universidade Federal de Alagoas, 2019. 106p. Tese Doutorado. http://www. repositorio.ufal.br/handle/riufal/5538. 22 Jun. 2019.

Fiorenza, M.; Dotto, D.B.; Bolignon, A.A.; Athayde, L.; Vestena, S. Análise fitoquímica e atividade alelopática de extratos de Eragrostis lana Nees (capim-annoni). Iheringia. Série Botânica, v.71, n.2, p.193-200, 2016. https://isb.emnuvens.com.br/ iheringia/article/view/536/300. 12 Jun. 2019.

Franco, D.M.; Saldanha, L.L.; Neto, J.S.L.; Santos, L.C.; Dokkedal, A.L.; Almeida L.F.R. Seasonal variation in allelopathic potential of the leaves of Copaifera langsdorffii Desf. Acta Botânica Brasilica, v.30, n.2, p.157-165. 2016. https://doi.org/10.1590/0102$33062015 a b b 0296$.

Fujii, Y.; Shibuya, T.; Nakatani, K.; Itani, T.; Hiradate, S.; Parvez, M. Assessment method for allelopathic effect from leaf litter leachates. Weed Biology and Management, v.4, n.1, p.19-23, 2004. https://doi.org/10.1111/j.1445-6664.2003.00113.x.

Golisy, A.; Lata, B.; Gawronski, S.; Fujii, Y. Specific and total activities of the allelochemicals identified in buckwheat. Weed Biology and Management, v.7, n.1, p.164-171, 2007. https://doi. org/10.1111/j.1445-6664.2007.00252.x.

Gonçalves, T.S. Interações ecológicas e evolutivas entre: Plantas, herbívoros e seus inimigos naturais. Agropecuária Científica no Semiárido, v.11, n.3, p.1-9, 2016. http://revistas.ufcg.edu.br/ acsa/index.php/ACSA/article/view/591/pdf. 02 Jul. 2019.

Kato-Noguchi, H.; Kobayashi, A.; Ohno, O.; Kimura, F.; Fujii, Y.; Suenaga, K. Phytotoxic substances with allelopathic activity may be central to the strong invasive potential of Brachiaria brizantha. Journal of Plant Physiology, v.171, n.7, p.525-530, 2014. https:// doi.org/10.1016/j.jplph.2013.11.010. 
Khawar, J.; Gulshan, M.; Virender, S.; Bhagirath, S.C. Allelopathy for weed control in agricultural systems. Crop Protection, v. 72, p. 57-65, 2015. https://doi.org/10.1016/j.cropro.2015.03.004

Konstantinović, B.; Blagojević, M.; Samardžić, N. Allelopathic effect of weed species Amaranthus retroflexus L. on maize seed germination. Romanian Agricultural Research, v.31, p.315-321, 2014.

Lanna, E. G.; Santos, C. F. B. A.; Souza, L. O.; Bittencourt, A. H. Avaliação preliminar de metabólitos secundários em Scoparia dulcis L. e atividade molúscida sobre Achatina fulica. Revista Científica da Faminas, v. 8, n. 2, 2012. https://periodicos.faminas. edu.br/index.php/RCFaminas/article/view/295. 22 Jun. 2019.

Nunes, J.V.D. et al. Atividade alelopática de extratos de plantas de cobertura sobre soja, pepino e alface. Revista Caatinga, v.27, n.1, p. 122-130, 2014. https://periodicos.ufersa.edu.br/index.php/ caatinga/article/view/2990. 10 Jun. 2019.

Oliveira, A.K.M.; Pereira, K.C.L.; Muller, J.A.I.; Matias, R. Análise fitoquímica e potencial alelopático das cascas de Pouteria ramiflora na germinação de alface. Horticultura Brasileira, v.32. n.1, p.41-47, 2014. https://doi.org/10.1590/S0102-05362014000100007.

Peloi, K.E.; Bovo, F.; Messias-Reason, I.J.; Perez, E. Utilização de planejamento fatorial para a determinação da capacidade antioxidante e doseamento de flavonoides totais em Verbena. Revista Brasileira de Plantas Medicinais, v.18, n.1, p.1-8, 2016. https://doi.org/10.1590/1983-084X/14_099.

Pereira, J.C.; Paulino, C.L.A.; Granja, B.S.; Santana, A.E.G.; Endres, L.; Souza, R.C. Potencial alelopático e identificação dos metabólitos secundários em extratos de Canavalia ensiformis L. Revista Ceres, v.65, n.3, p.243-252, 2018. https://doi.org/10.1590/0034737x201865030004.

Pirzad, A.; Ghasemian, V.; Darvishzadeh, R.; Sedghi, M.; Hassani, A.; Onofri, A. Allelopathy of sage and white wormwood on purslane germination and seedling growth. Notulae Scientia Biologicae, v.2, n.3, p.91-95, 2010. https://doi.org/10.15835/nsb234811.
Santos, S.; Rezende, M.O.O. Avaliação do potencial herbicida de compostos secundários na germinação de sementes de plantas daninhas encontradas em pastagens. Revista Analytica, n.32, p.72-78, 2008.

Silveira, B.D.; Hosokawa, R.T.; Nogueira, A.C.; Weber, V.P. Araucaria angustifolia (Bertol.) Kuntze allelopatic activity on germination and initial growth of Lactuca sativa L. Ciência Florestal, v. 24, n. 1, p. 79-85, 2014. https://doi.org/10.5902/1980509813325.

Souto, J.S.; Borges, C.H.A.; Medeiros, W.P.; Leonardo, F.A.P.; Souto, P.C.; Souto, L.S. Potencial alelopático do extrato aquoso de folhas de moringa na germinação e no crescimento inicial da alface. Agropecuária Científica no Semiárido, v.11, n.2, p.56-60, 2015. http://revistas.ufcg.edu.br/acsa/index.php/ACSA/article/ view/650/pdf. 12 Jun. 2019.

Souza Filho, A.P.S. Alelopatia: princípios básicos e mecanismos de interferências. In: Monquero, P.A. (Org.). Aspectos da biologia e manejo das plantas daninhas. São Carlos: RiMa, 2014. p. 83-101.

Souza, V.C.; Hassemer, G. Plantaginaceae in Lista de Espécies da Flora do Brasil. Rio de Janeiro: Jardim Botânico do Rio de Janeiro, 2015. http://floradobrasil.jbrj.gov.br/jabot/floradobrasil/FB137657. 02 Jul. 2019.

Streibig, J.C. Herbicide bioassay. Weed Research, v.28, n.6. p. 497-484, 1988. https://doi.org/10.1111/j.1365-3180.1988.tb00831.x.

Yamagushi, M.Q.; Gusman, G.S.; Vestena, S. Potencial alelopático de extratos aquosos e Bidens pilosa L., Cyperus rotundus L. e Euphorbia heterophylla L. Iheringia. Série Botânica, v.66, n.1, p.87-98, 2011. https://isb.emnuvens.com.br/iheringia/article/ view/63. 02 Jul. 2019.

Zhi-Cong, D.; Xiao-Ying, W.; Shan-Shan, Q.; Hong-Hong, C.; JianFan, S.; Ping Huang, D.L. Effects of leaf litter on inter-specific competitive ability of the invasive plant Wedelia trilobata. Ecological Research, v.31, n.3, p.367-374, 2016. https://doi. org/10.1007/s11284-016-1344-0. 